\title{
A primer on structured finance
}

\author{
Andreas A. Jobst \\ International Monetary Fund (IMF), Monetary and Capital Markets Department (MCM), \\ 700 19th Street, NW, Washington DC 20431, USA. \\ Tel. +1 202623 6362, Fax: + 1202589 6362, E-mail: ajobst@imf.org
}

Received (in revised form): 7th June, 2007

\begin{abstract}
Andreas (Andy) Jobst is a mid-career economist at the Monetary and Capital Markets Department (MCM) of the International Monetary Fund (IMF) in Washington, DC. His research focuses on structured finance, risk management, sovereign debt management, emerging market finance and economics, financial regulation, and time series econometrics. He previously worked at the Division for Insurance and Research at the Federal Deposit Insurance Corporation (FDIC), the Economics Department of the Deutsche Bundesbank, the Financial Markets Group (FMG) at the London School of Economics (LSE), the Center for Financial Studies (CFS) in Frankfurt/Main, the International Division of the European Central Bank (ECB), the Financial Institutions Division of the Bank of England, the Comisión Económica para América Latina y el Caribe (CEPAL) of the United Nations, the European Securitization Group of Deutsche Bank in London, and the Financial Services Group of the Boston Consulting Group (BCG). He holds a PhD in Finance from the London School of Economics (LSE). He was also educated in Oxford, Cambridge, Leicester and Maryland, and holds the professional qualification of Accredited Asset Management Specialist (AAMS).
\end{abstract}

\section{Practical applications}

The article helps uninitiated market participants, policy makers and regulators understand the technical aspects and economic characteristics of structured finance in a bid to promote the development of market practices and prudential standards that guarantee market stability without encumbering the welfare-enhancing effect of risk sharing and efficient market pricing.

\begin{abstract}
On the heels of last year's downgrades of General Motors Corp. and Ford Motor Co. to noninvestment grade status, the haircut unwinding of exposed collateralised debt obligations reverberated in mounting regulatory unease about current risk measurement standards of derivatives and their impact on financial stability. Probable knock-on effects of the recent bankruptcies of US auto parts supplier Delphi and two major airlines have fuelled groundswell concern about complex structured finance techniques, such as customised singletranche and hybrid collateralised debt obligations with

overlay structures, against the background of tightening credit spreads and greater dislocation in the correlation market. Subsequent warnings about the resilience of credit risk transfer to systemic crisis, however, hardly
\end{abstract}

Journal of Derivatives \& Hedge Funds, Vol. 13 No. 3, 2007, pp. 199-213 (C) 2007 Palgrave Macmillan Ltd $1753-9641 \$ 30.00$ extended beyond indistinct assessments of how derivatives might propagate asset shocks across different capital market segments. This brief paper defines structured finance in order to inform a more specific debate about the regulatory challenges posed by the assembly of asset exposures and credit risk transfer in complex structured finance transactions that marry considerations of profitability and diversification alike.

Journal of Derivatives \& Hedge Funds (2007) 13, 199-213. doi:10.1057/palgrave.jdhf. 1850070

Keywords: structured finance; credit risk transfer; asset-backed securitisation (ABS); securitisation; mortgage-backed securitisation (MBS); collateralised debt obligation (CDO) 


\section{INTRODUCTION}

The traditional view of financial stability concentrates analytical efforts on the identification of increasing vulnerabilties prior to stress from individual failure in institutions, markets and infrastructure, assuming that the financial system is in equilibrium and adjusts when it experiences a shock. As opposed to this conventional approach, the presence of systemic vulnerabilties warrant the monitoring of ongoing developments in evolving areas of financial markets where the impact of unsustainable imbalances on financial stability is deemed most severe and widespread but difficult to measure, leave alone forecast. Given the increasing sophistication of financial products, the diversity and global reach of financial institutions, as well as the growing interdependence of financial markets and services, such areas exposed to extreme scenarios are likely to be found in financial innovation, where market forces and participants are left to their own devices and when complex incentive structures encourage greater risk taking in a benign economic environment but entail more adverse economic consequences when stress occurs.

One case in point is the development of the structured finance market, which has benefited from the attractive proposition of greater risk diversification. On the heels of prominent corporate downgrades in the US in April 2005, corporate defaults, such as auto parts supplier Delphi (see Box 1), and the recent jitters in the US sub-prime mortgage market during the first quarter of 2007, the haircut unwinding of exposed collateralised debt obligations (CDOs) and other securitisation transactions reverberated in mounting regulatory unease about current risk measurement standards of derivatives and the possible knock-on effects of the structured finance market on other investment classes. After the fallout of the high-profile bankruptcies of automotive supplier Delphi as well as Northwest and Delta airlines in November 2005 , investors and regulators began to worry about the systemic resilience of complex structured finance techniques (such as customised single-tranche hybrid CDOs with overlay structures) - especially against the background of tightening credit spreads and greater dislocation in the correlation market. The subsequent drumbeat of warnings about the impact of leveraged structured claims on financial stability in times of stress, however, hardly extended beyond indistinct assessments of the mechanics of structured finance markets and the ability of different structured finance products to propagate asset shocks across different capital market segments.

This brief paper defines structured finance in order to inform a more specific debate about the regulatory challenges posed by the assembly of asset exposures and credit risk transfer in complex structured finance transactions that marry considerations of profitability and diversification alike.

\section{DEFINITION OF STRUCTURED FINANCE}

Structured finance encompasses all advanced private and public financial arrangements that serve to efficiently refinance and hedge any profitable economic activity beyond the scope of conventional forms of on-balance sheet securities (debt, bonds, equity) at lower capital cost and agency costs from market impediments and liquidity constraints. In particular, most structured investments (i) combine traditional asset classes with contingent claims, such as risk transfer derivatives and/or derivative claims on 
commodities, currencies or receivables from other reference assets, or (ii) replicate traditional asset classes through synthetication or new financial instruments. Structured finance is invoked by financial and nonfinancial institutions in both banking systems and capital markets if either (i) established forms of external finance are unavailable (or depleted) for a particular financing need, or (ii) traditional sources of funds are too expensive for issuers to mobilise sufficient funds for what would otherwise be an unattractive investment based on the issuer's desired cost of capital. Structured finance offers issuers enormous flexibility to create securities with distinct risk-return profiles in terms of maturity structure, security design, and asset type, providing enhanced return at a customised degree of diversification commensurate to an individual investor's appetite for risk. Hence, structured finance contributes to a more complete capital market by offering any mean-variance trade-off along the efficient frontier of optimal diversification at lower transaction cost. The increasing complexity of the structured finance market, and the ever-growing range of products being made available to investors, however, invariably create challenges in terms of efficient management and dissemination of information.

The premier form of structured finance is predicated on capital market-based risk transfer (save for loan sales, asset swaps and natural hedges through bond trading (see Figure 1)), whose two major asset classes include asset securitisation (which is mostly used for funding purposes) and credit derivative transactions (as hedging instruments) permit issuers to devise almost an infinite number of ways to combine various asset classes in order to both transfer asset risk between banks, insurance companies, other money managers and nonfinancial investors in order to achieve greater transformation and diversification of risk.

Asset securitisation describes the process and the result of converting (or monetising) a pool of designated financial assets into tradable liability and equity obligations as contingent claims backed by identifiable cash flows from the credit and payment performance of these asset exposures. ${ }^{1}$ From an issuer perspective, securitisation registers as an alternative, market-based source of refinancing profitable economic activity in lieu of intermediated debt finance. Securitisation seeks to substitute capital market-based finance for credit finance by sponsoring financial relationships without the lending and deposit-taking capabilities of banks (disintermediation).

Issuers raise funds via securitisation in order to improve their capital management and liquidity position without increasing the capital base. The implicit risk transfer of securitisation allows issuers to benefit from more cost-efficient terms of high-credit quality finance without increasing their on-balance sheet liabilities or compromising the profit-generating capacity of assets. Investors in securitisation have a wider choice of high-quality investments at their disposal, whose market valuation engenders greater overall efficiency and liquidity of capital markets. Securitisation, however, involves a complex structured finance technology, which commands significant initial investment of managerial and financial resources.

Aside from being a flexible and efficient source of funding, the off-balance sheet treatment of securitisation also serves (i) to reduce both economic cost of capital and regulatory minimum capital requirements as a balance sheet restructuring tool (regulatory and economic motive) and (ii) to diversify asset exposures (especially interest rate risk and 


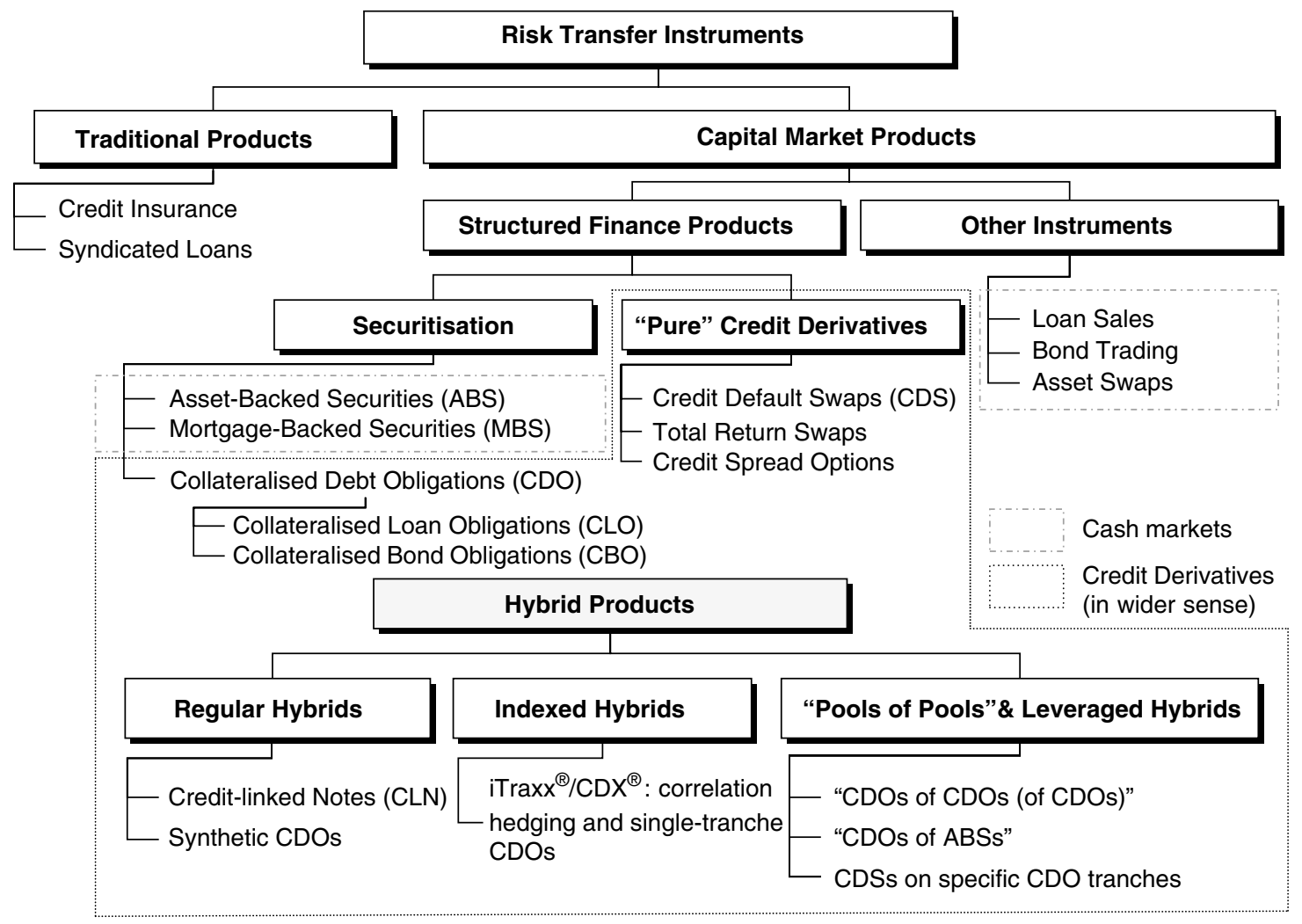

Figure 1: Overview of risk transfer instruments

currency risk). The generation of securitised cash flows from a diversified asset portfolio represents an effective method of redistributing asset risks to investors and broader capital markets (transformation and fragmentation of asset exposures). As opposed to ordinary debt, a securitised contingent claim on a promised portfolio performance affords investors at low transaction costs to quickly adjust their investment holdings due to changes in personal risk sensitivity, market sentiment and/or consumption preferences.

Derivatives in general are financial contracts on a pre-determined payoff structure of securities, indices, commodities or any other assets of varied maturities. Derivatives assume economic gains from both risk shifting and efficient price discovery $^{2}$ by providing hedging and low-cost arbitrage opportunities. Risk diversification improves the pricing of risk, increases stability at all levels of the financial system, and enhances general welfare. In addition to their capacity of eliminating or attenuating risk, derivatives also supplement cash markets as alternatives to trading underlying assets.

Credit derivatives are financial instruments that isolate and transfer credit risk. As a common working principle, they involve the sale of contingent credit protection for pre-defined credit events and/or asset performance. In their basic concept, the sale of credit derivatives severs the link between the loan origination and associated credit risk, but leave the original borrower-creditor relationship intact. The 
protection buyer of a credit derivative hedges specific credit risk at the expense of periodic premium payments to the protection seller, who assumes the credit exposure of of the underlying transaction. ${ }^{3}$ The significance of credit derivatives lies less in their market share next to other derivative instruments (eg interest rate and foreign exchange derivatives) but in their ability to supplement traditional ways of hedging credit risk through the transfer of credit-related exposures to a third party. Other, noncredit derivative-based forms of credit risk transfer include credit insurance, syndicated loans, loan sales, bond trading and asset swaps (Box 1).

We distinguish between credit derivatives in the narrower and in a wider sense. ${ }^{5,6}$ The broader classification of derivatives includes (i) pure credit derivatives, such as credit default swaps (CDSs), total return swaps and credit spread options, which fall within the narrow definition of credit derivatives, as well as (ii) hybrid and securitisation products with constituent credit derivative elements, such as traditional or true sale CDOs of bonds and loans and partially funded or unfunded structured finance transactions, for example credit-linked notes (CLNs), synthetic CDOs and other credit derivative-based hybrid products (see Figure 1). Hybrid structures employ securitisation ${ }^{7}$ for refinancing (through cash flow restructuring) and tranche-specific credit risk transfer $^{8}$ (though the sale of credit protection or the issuance of leveraged super-senior (LSS) 9,10 tranches). These hybrid and securitisation products are considered credit derivatives in a wider sense, which usually condition the repayment of securitised debt on a defined credit event in a bilateral hedge (in the case of CLNs), the premium income generated from credit protection sold on reference assets (in the case of synthetic CDOs), or the returns from investing and/or writing credit protection (long position on credit risk) on diversified pools of securitisation transactions of CDOs and/or assetbacked securities (ABSs) ('pools of pools') or newly formed CDSs and collateralised debt indices (eg the Dow Jones $i \operatorname{Trax} x^{\circledR}$ and the $i B o x x^{\circledR}$ index), ${ }^{11-13}$ and the composite $A B X^{\mathbb{R}}$ indices of CDS on ABS (ABCDS). ${ }^{14}$

CDOs have been the fastest growing area of structured finance. ${ }^{15}$ The CDO market has rapidly evolved since 1996, when the sector first gained significant prominence after its inception in the late 1980s, when some US banks started using CDOs as expedient risk-transfer mechanism. CDOs have now become a globally accepted structured finance technique, spanning the US, Europe and large parts of Asia. CDOs are investment vehicles that allow issuers to refinance the purchase of debt instruments by repackaging them into different slices of risk and maturity. While CDOs use the same structuring technology as ABS to convert a large, diversified pool of exposures into tradable commercial papers (tranches), their underlying collateral pool typically includes a wider and more diverse range of heterogeneous reference assets, such as senior secured bank loans, high yield bonds and CDSs, as opposed to more homogenous titles, such as home equity loans and credit card receivables. ${ }^{16}$

A CDO transaction is arranged and administered like a 'managed fund' with debt and equity holders, where a designated reference portfolio represents a diversified exposure to one or more asset classes from different issuers and/or industry sectors. Conversely, CDO investors sell credit protection to issuers against default on a portion of underlying reference assets. Generally, managers of CDO collateral portfolios choose a certain degree of diversification for a prespecified risk-return profile subject to limits 


\section{Box 1: The lessons of Delphi case and recovery rate products}

The economic fallout caused by the bankruptcy of Delphi did not result from inappropriate risk management and speculation, but reflected inefficiencies in the microstructure of derivative markets at the time of settlement. ${ }^{4}$ When doubts about Delphi's creditworthiness emerged, the prospect of a shortage of deliverable debt increased the price (and reduced the attendant average recovery rate) of CDS-based credit protection beyond the level that might have otherwise been justified by the expected repayment from debt resolution (implied by rating agencies' estimates of Delphi's ultimate recovery rate or settlement prices of comparable firms). Higher transaction costs incurred by scarcity of collateral deterred trading of physical delivery CDS contracts (for lack of demand), because protection buyers would have had to settle contracts on overpriced collateral, thereby discounting their recovery value implied by par value compensation through the CDS contract. Cash settled CDS contracts would not have implied such recovery risk.

Sellers of credit protection via CDS contracts are constantly exposed to recovery risk, while protection buyers are faced indirectly with recovery rate risk if the underlying asset (or a surrogate cheapest-to-deliver (CTD) asset) trades above the fair market price (suggested by the projected recovery rate) due to limited asset diversity when market liquidity is poor.

Several products permit investors to hedge recovery risk separately from default risk in derivative contracts. As opposed to a plain vanilla CDS contract, where the protection seller is exposed to recovery rate risk upon default of the underlying reference asset, a fixed recovery rate $C D S$, for instance, eliminates the uncertainty on the recovery rate by fixing a specific recovery value over the maturity of the CDS contract. After a credit event, the protection buyer is entitled to a cash settlement equal to 100 minus the pre-specified, fixed recovery rate. Recovery CDS with a fixed recovery rate set to zero are referred to as zero recovery CDS. Such products could serve as pricing benchmarks in the wake of a credit event, fostering a more efficient settlement process.

A recovery lock is a cash-neutral forward contract that fixes the recovery rate irrespective of the settlement price of the underlying reference asset. In practice, a recovery lock is structured by means of two opposite trades on the same reference entity. Protection sellers hedge themselves against recovery rate risk of their long position in a plain vanilla CDS by purchasing protection through a fixed recovery CDS. If the implicit recovery rate of the conventional CDS contract concurs with the fixed recovery rate, the premium payments on the transactions wash out and net to zero. In this case, if the reference entity defaults, the protection buyer of the fixed recovery CDS delivers the defaulted debt to the recovery seller and receives compensation equal to 100 minus the pre-specified, fixed recovery rate, which, in turn, pays off the compensation claim under the issued plain vanilla CDS contract. If the premium payments of the two trades differ, for example the actual recovery of the underlying asset drops below the fixed recovery rate at the time of default, the protection buyer reinvests higher premium income from the short position of a plain vanilla contract into fixed recovery rate protection on a larger notional value.

and guidelines that are determined by the issuers, rating agencies and investors at the commencement of the transaction.
In a CDO structure asset managers can increase assets under management while locking in committed funds and achieving some 
protection from market value volatility. While cash CDOs are backed by a collateral of actual bonds and loans as reference assets, whose legal title is transferred to the purchaser, issuers of synthetic CDOs enlist wads of credit derivatives and various third-party guarantees to create unfunded or partially funded, highly leveraged investment from synthetic claims on the performance of designated credit exposures. ${ }^{17}$ CDOs involve either cash flow or arbitrage mechanisms to either fund expected principal and interest payments or expected trading and sales activity. CDOs enable issuers to achieve a broad range of financial goals, which include the off-balance sheet treatment of securitised exposures, reduced minimum regulatory capital requirements and access to alternative sources for asset funding and liquidity support. The conventional security design of CDOs assumes a typical three-tier securitisation structure of junior, mezzanine and senior tranches, which concentrates expected losses in a small first loss position as equity claim, which bears the majority of the credit exposure and is frequently covered by a junior CDS, shifting most unexpected risk to larger, more senior tranches, which display distinctly different risk profiles. ${ }^{18,19}$ This risk sharing arrangement induces a leverage effect on constituent tranches, whose distinct risk-return profiles can be tailored to specific investment preferences. ${ }^{20}$

\section{BOUNDARIES BETWEEN STRUCTURED FINANCE AND CONVENTIONAL FINANCE}

The flexible nature of structured finance straddles the indistinct boundary between traditional fixed income products, debentures and equity on one hand and derivative transactions on the other hand. Notwithstanding the ostensible difficulties of defining structured finance, a functional and substantive differentiation seems to be most instructive for guiding an informed demarcation between the most salient properties of structured and conventional forms of external finance. The following definition reflects such a proposition if we compare two financial arrangements:

(a) Investment instruments are motivated by the same or similar financial objective from both the issuer's and the investor's point of view, but a dissimilar legal and functional implementation requires a different valuation.

(b) Investment instruments are motivated by the same or similar financial objective and are substantively equivalent (ie they share a close equilibrium price relation and the same investor pay-off profile), but differences in transaction structure and/or security design necessitate a different valuation.

In the first case, pure credit derivatives are clear examples of structured products, which allow very specific and capital-market priced credit risk transfer (see Figure 1). Credit insurance and syndicated loans share the same financial objective; however, they do not constitute an arrangement to create a new risk-return profile from existing or future reference assets. In the same vain, mortgage-backed securities (MBSs) and Pfandbrief-style covered mortgage bonds represent different functional and legal methods of securitisation with the same financial objective. Although both refinancing techniques convert homogenous pools of mortgage claims into negotiable securities, they represent two distinct forms of debt securities issued on the same type of underlying reference asset either 
off-balance sheet (asset-backed securitisation), on-balance sheet ('Pfandbrief-style' securitisation) or even through synthetic securitisation.

The Pfandbrief is the most prominent deal structure for securitised mortgage loans in Europe, which matches the importance of MBS in the US by issuance volume, trading activity and historical track record (see Box 2). In contrast to the US, where the market for MBS has had a longstanding tradition since the first half of the 1980s, ${ }^{23}$ off-balance sheet securitisation via MBS is a relatively recent development in Europe and has gained traction only over the last years, with issuance amounts being still relatively low compared to established on-balance sheet securitisation via covered mortgage bonds or Pfandbrief. ABS issues have caught up with Pfandbrief transactions. The Pfandbrief market is still the biggest segment of the euro-denominated private debt market and rivals in size the individual government bond markets in Europe. ${ }^{24-25}$ Whereas originators of Pfandbrief issues retain securitised assets on their balance sheet, issuers of MBSs sell assets to a separate legal entity (such as trust, fund and corporation), commonly referred to as a special purpose vehicle (SPV), which refinances the acquisition of the assets by issuing debt (eg bonds or commercial paper) or equity claims on the back on these reference assets. The designated assets are considered securitised insofar as their cash performance serves to secure any repayment obligation to investors. Alternatively, synthetic securitisation represents a compound form of structured finance, which amalgamates properties of both asset-backed securitisation and credit derivatives in one coherent structure. Synthetic securitisation does not involve the transfer of assets, but serves to hedge the credit risk to which the originator is exposed.
The originator merely transfers the credit risk through the use of funded (eg credit-linked notes (CLNs)) or unfunded (eg CDSs) credit derivatives or guarantees, in which the counterparty agrees upon specific contractual covenants to cover a predetermined amount of losses. ${ }^{26}$

In the second case, for instance, Islamic finance falls squarely within the domain of structured finance instrument whenever religious constraints require the replication of conventional interest-bearing assets through structural arrangements of two or more contingent claims (see Figure 2). Islamic finance is limited to financial relationships involving entrepreneurial investment, subject to the prohibition of (i) interest earnings (riba) and money lending, (ii) sinful activity (haram), ${ }^{27}$ such as direct or indirect association with lines of business involving alcohol, tobacco, pork products, firearms and gambling, and (iii) the speculative trade or exchange of money for debt without an underlying asset transfer (gharar). ${ }^{28}$ As opposed to conventional finance, where interest represents the contractible cost for funds over a pre-specified lending period, in Islamic finance, both financiers and borrowers to share the business risk (and returns) from investment in religiously acceptable services, trade or products (in adherence to lawful activities) (halal), where profits are not guaranteed ex ante, but only accrue if the investment itself yields income. Islamic financial transaction assigns to investors clearly identifiable rights and obligations for which they are entitled to receive commensurate return. ${ }^{29}$

In light of these moral impediments to both 'passive' investment and interest as form of compensation, shariah-compliant lending in Islamic finance requires the replication of interest-bearing, conventional finance via 


\section{Box 2: The definition of Pfandbrief transactions}

Although many European countries have already put in place legal frameworks for Pfandbrief-style products, the German Pfandbrief (literally 'letter of pledge') is the eponym of this type of covered mortgage bond. ${ }^{21}$ Although the creation of the first Pfandbrief instrument was attributed to an executive order of Frederick II of Prussia in $1769,{ }^{22}$ it was only when the Mortgage Bank Law was passed in 1899 that the Pfandbrief took its present form. The first legal guidance for the issuance of Pfandbrief-style products was actually adopted in France in 1852 with the Loi sur l'obligation foncière et communale. The oldest mortgage credit market can be traced to Denmark, when the Great Fire of 1789 created vast demand for housing finance in its wake. In Sweden, a mortgage market has existed at least since 1860 under the legal provisions of the more general Law on Credit Companies, but no specific mortgage bank law has been issued so far.

While the Pfandbrief is a classical on-balance sheet refinancing tool of mortgages and public loans with both origination and issuance completed by one and the same entity, MBS transactions are off-balance sheet transactions and involve at least one more party (besides the mortgage originator). Pfandbrief serve primarily as funding instruments, whereas MBS issues are also employed for credit risk transfer and balance sheet restructuring, with the aim of efficient management of economic and regulatory capital. Originators of MBS sell contingent claims on asset cash flows in order to remove and legally segregated ('bankruptcy remote') reference portfolio of securitised assets from the balance sheet. In contrast, in a typical German Pfandbrief transaction, reference assets are 'ring-fenced' on the balance sheet of government-licensed issuers and repayments to investors are independent from the repayment of securitised assets. Issuers of Pfandbrief deals are fully liable with their registered capital if reference assets fail to generate sufficient cash flows for the repayment of investors. Hence, this arrangement implies a double protection of investors against credit risk and the solvency of the issuer. Given the value of this institutional guarantee depending on the issuer's financial strength, Pfandbrief transactions generally receive high ratings. However, in comparison, MBS transactions are devoid of any institutional guarantee and solely return cash flows generated from the pool performance of the designated reference portfolio. Issuers of MBS transactions compensate issuers for the higher asset exposure due to the lack of institutional protection by including various kinds of internal and external liquidity and credit support, such as bridge-over facilities, surety bonds, third-party guarantees, excess spreads, over-collateralisation and reserve accounts. Finally, Pfandbrief issues are typically subject to stringent federal laws (requiring a weighted average loan-to-market (or appraised) value (LTV) of at least 60 per cent as a statutory benchmark), while private-label MBS issues are free from these legal requirements, except in so-called agency-MBS in the US, where the quasi-government agencies Fannie Mae (FNMA), Freddie Mac (FHLMC) and Ginnie Mae (GNMA) provide institutional guarantees in return for certain restrictions imposed on mortgages eligible for purchase in MBS structures.

In general, Pfandbrief transactions represent a very secure and liquid asset class of fixed income instruments with an established track record and cyclical resilience. MBS issues are equally liquid (at least in the US market) and feature an unchallenged degree of structural flexibility allowing for customised features and investor arrangements, such as variations to amortising repayment (in contrast to bullet repayment structures of Pfandbrief issues) and security design. 


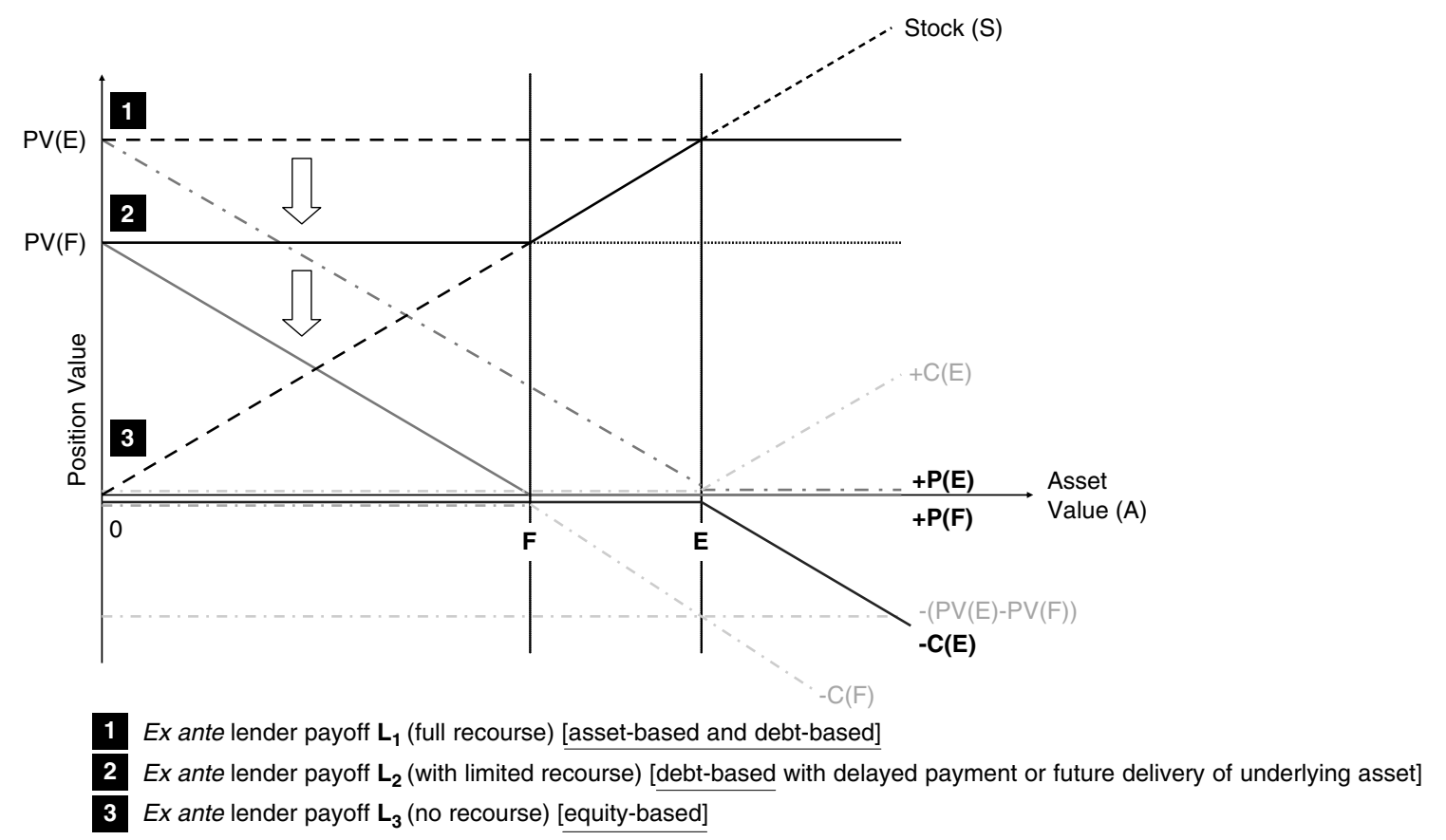

Figure 2: The pay-off profile under put-call parity of the three basic Islamic finance transactions

structural arrangements of contingent claims. Although Islamic and conventional finance are equivalent in terms of substance and yield the same lender and investor pay-offs (ie equilibrium price equivalence) at the inception of the transaction, they differ in legal form and might require a different valuation due to dissimilar transaction structures and/or security design.

As opposed to conventional lending, Islamic finance substitutes a temporary transfer of an asset to the lender for a permanent transfer of funds to the borrower as a source of indebtedness. We distinguish between three basic forms of Islamic financing methods for both investment (eg plant, equipment, machines) and trade finance: ${ }^{30-32}$ (i) synthetic (mortgage) loans (debt-based) ${ }^{33}$ through a salerepurchase agreement or back-to-back sale of borrower- or third party-held assets, (ii) operating or finance leases (asset-based) ${ }^{34}$ through a leasebuyback agreement or purchase order, and (iii) profit-sharing contracts (equity-based) ${ }^{35}$ of future assets (see Figure 2). As opposed to equity-based contracts, both debt- and assetbased contracts (in their generic form) are initiated by a temporary transfer of existing assets from the borrower to the lender or the acquisition of third-party assets by the lender on behalf of the borrower. ${ }^{36}$ These different forms of Islamic finance combine two or more contingent claims to replicate the risk-return trade-off of conventional lending contracts or equity investment without any contractual guarantee of investment return or payments by reference to an interest rate as time-dependent cost of funds. ${ }^{37}$

This unsecured arrangement constitutes entrepreneurial investment on part of the 
financier, who receives returns from direct participation in uncertain asset performance in the form of state-contingent payments according to an agreed schedule and amount. ${ }^{38}$ The specific lending arrangement underlying each type of Islamic finance represents a different form of a put-call parity ${ }^{39}$-based replication of interest income, which re-characterises the rate of return of conventional investments in a religiously acceptable manner.

The three main types of Islamic finance are only distinct as to the attribution of economic benefits from the use of an existing or future asset owned by the lender. In asset-based Islamic finance for investment or trade, the borrower leases from the lender one or more assets $A$ at current stock value $S$, which the lender has previously acquired either from the borrower or a third party. The lender writes a call option $C$ with strike price $E$ to the borrower to acquire the asset after time $T$, subject to the promise (put option $P$ ) of full payment $E$ of the current asset price plus an agreed premium in the form of total rental payments over the investment period, which amounts to a present value of $P V(E)$ of risky debt at maturity. If the lender has full recourse (ie he retains ownership until maturity $T$, when the borrower can exercise the right to acquire the asset), also the put option has a strike price $E$, which ensures that the borrower's failure to fully repay entitles the lender to sell the asset to compensate for the financial shortfall.

This arrangement amounts a collateralised loan with maturity $T$ and a fully collateralised principal amount, which is equivalent to the current purchase price of the desired asset.

According to put-call parity, the lender's position at maturity is $S-C(E)+P(E)=P V(E),{ }^{40}$ which equals the present value of the principal amount and interest of a conventional loan. In a more realistic depiction, the combination of a held put and a written call option on the same strike price does not represent a simple forward contract on the underlying asset, but a series of forward contracts over multiple rental payment dates, each of which obliging the holder to renew the periodic call option of purchasing the asset at maturity as a buyback or allowing the lender to resell the asset at final maturity. ${ }^{41}$

In debt-based and equity-based Islamic finance, the payoff profiles are similar. In debt-based Islamic finance, borrower indebtedness from a sale-repurchase agreement of an asset with current value $P V(E)$ implies a premium payment to the lender for the use of funds over the investment period $T$. As opposed to an asset-based arrangement, the lender relinquishes same asset ownership right after inception, if there is a mismatch of funding and repayment reducing the option value of possible recourse (written put) to $P(F)$, so that ex ante lender payoff $L_{2}$ is now $S-C(E)+P(F)=P V(F)-(P V(E)-$ $P V(F))-C(F)+C(E)$. In equity-based Islamic finance, the lender (ie investor) is fully repaid only if the investment project generates high enough returns to repay the initial investment amount and the premium payment in return for investment risk until maturity $T$. This arrangement precludes any recourse by the lender. If the investor owns 100 per cent equity of investment $S$, ex ante lender payoff $L_{3}$ is $S-C(E)=P V(E)+P(E)$.

\section{CONCLUSION}

Against the background of rising regulatory unease about the evolution of derivative markets, we argue that a clear-cut definition of structured finance helps substantiate more viable debate about the resilience of credit risk transfer 
to financial shocks. Structured finance

encompasses all advanced private and public financial arrangements that serve to efficiently refinance and hedge any profitable economic activity beyond the scope of conventional forms of on-balance sheet securities (debt, bonds and equity) in the effort to lower cost of capital and to mitigate agency costs of market impediments on liquidity. Especially, the distinction of the various methods of credit risk transfer through credit derivatives in a wider and narrower sense as well as securitisation transactions illustrates the need for more comprehensive and creative regulatory considerations that take on board the heterogeneity of institutions, markets, and infrastructure.

\section{DISCLAIMER}

The views expressed in this paper are those of the author and should not be attributed to the International Monetary Fund, its Executive Board, or its management. Any errors and omissions are the sole responsibility of the author. An earlier version of this paper is available at http://papers.ssrn.com/sol3/ papers.cfm?abstract_id $=832184$.

\section{References and Notes}

1 Jobst, A. (2006a) 'Sovereign Securitization in emerging markets', Journal of Structured Finance, Vol. 12, No. 3, pp. 2-13.

2 Derivatives help "discover" the fair market price (spot and future) of certain assets or risks in instances of high transaction costs, poor liquidity due to the dispersion of markets, limited asset supply or the conglomeration of many risks into one whole asset.

3 In a cash-settled CDS, the protection seller is required to make a settlement payment in the amount of the difference between the notional principal and the market price of the underlying bond or the reduced recovery value of the defaulted bank credit. Alternatively, in what has increasingly become the market norm, physical settlement CDSs oblige the protection seller to accept the reference asset (or any other eligible collateral asset, such as cheapest-to-deliver (CTD) bonds) against payment of their par value. Unlike credit insurance contracts, credit derivatives are negotiable and attract large secondary trading.

4 Micu, M. and Upper, C. (2006) 'Derivative Markets', BIS Quarterly Review, Bank for International Settlements (BIS), 47.

5 Jobst, A. (2006b) 'Correlation, price discovery and comovement of ABS and equity', Derivatives Use, Trading E Regulation, Vol. 12, No. 1-2, pp. 60-101.

6 Effenberger, D. (2003) 'Frankfurt Voice: Credit Derivatives - Implications for Credit Markets', Deutsche Bank Research.

7 This feature does not apply to plain vanilla asset-backed securities (ABS) and mortgage-backed securities (MBS).

8 Although the transformation and fragmentation of credit risk through securitisation brings greater diversification within the financial system, the structural complexity arising from multi-layered security designs, diverse amortisation schedules and the state-contingent funding of synthetic credit risk transfer might obfuscate actual riskiness of these investments and inhibit provident investment. The tradability of credit risk facilitates the synthetic assembly and dynamic adjustment of credit portfolios via secondary markets, but numerous counterparty links established in the commoditisation of securitised asset risk and wads of derivative claims also create systemic dependence susceptible to contagion on the risk of heightened aggregate moral hazard. This prospect of leveraged investment in synthetic structures seems to be particularly troubling when investors take on more risks for yield during times of compressed spreads and rising default rates when credit cycles approach their turningpoint. Moreover, the contingent liability of credit derivatives as credit protection of securitised assets requires the protection seller to put up liquidity only if a credit event occurs.

9 'Market developments testify to "structural substitution" in complex hybrid CDOs. After CDOsquareds ("CDOs of CDOs") led to the narrowing of mezzanine spreads in the CDO market, leveraged supersenior tranches (SS) with marked-to-market (MTM) lossand spread-based triggers emerged in a significant number of synthetic CDOs. Most recently, investment banks with significant mezzanine ABS inventory also began to employ leveraged super-senior (LSS) tranches in synthetic CDOs as an alternative method of hedging specific - and not diversified - mezzanine tranche exposure by offloading senior risk instead of selling credit protection or delta hedging. With the leveraged super-senior concept becoming exhausted, CDO 
managers are now introducing overlay structures that bring in other sources of risk, such as foreign exchange rates, inflation and commodity price linkages in order to juice up investor yields. ${ }^{7}$ Super-senior tranches themselves are usually secured by a CDS as a means of improving the marketability of issued claims.

10 Jobst, A. (2005) 'Risk Management of CDOs During Times of Stress', Derivatives Week, Euromoney, London, 28 November.

11 Both the Dow Jones $i \operatorname{Trax} x^{\mathbb{R}}$ Europe index of credit default swap (CDS) contracts and the $i B o x x^{\mathbb{R}}$ index of collateralised (fixed-rate) debt obligations have inaugurated the first round of emerging standardisation. A recent survey paper by Cousseran and Rahmouni ${ }^{12}$ states that the development of liquid pricing benchmarks has greatly contributed to the maturity of the market for collateralised debt obligations (CDOs) as regards 'an improvement in the transparency of the market, as tranche prices are continuously quoted; a significant increase in market liquidity [...], allowing protection to be bought and sold at a lower cost $[\ldots]$, an improvement in the management of market participants' risk, as they now have access to daily valuations from which they can obtain [...] levels of implied correlation [...], [and] a broadening of the investor base to new market participants such as hedge funds, which use these instruments for their sophisticated trading strategies (correlation trading).' Large parts of the ABS market in Europe have, however, shed little of their frequently deplored opacity. Market observers do not find a dramatic change in market transparency due to standardisation as much as they acknowledge changing hedging patterns of ABS issues in its wake. ${ }^{13}$ For instance, CDOs are generally structured to meet specific investor needs. In the past, issuers would hedge unbalanced positions of customised CDOs through complex subordinated, multi-tranche structures ('transaction-based'), whose complexity inhibited transparent asset pricing. When the Dow Jones $i \operatorname{Trax} x^{\mathrm{B}}$ Europe index was created in June 2004 from the merger between two existing CDS indices, large issuers began to offer standard (single) CDO tranches on the $i \operatorname{Trax} x^{\circledR}$ index, which replicate the behaviour of synthetic CDO claims on constituent names of the Dow Jones $i \operatorname{Trax}{ }^{\mathbb{R}}$ index. These standardised (synthetic) CDO claims on liquid indices now offer a base correlation measure ('CDO delta') with the actual equity prices of (underlying) reference assets and constitute a dynamic 'market-based' hedge for issuers of bespoke and mostly privately transacted single-tranche transactions (arranged for single investors). Most recently, issuers also began to offer multi-tranche transactions with mezzanine tranches indexed to equity prices and tranche-specific CDS contracts on any retained CDO interest.

12 Cousseran, O. and Rahmouni, I. (2005) 'The CDO Market - Functioning and Implications in Terms of Financial Stability', Banque de France Financial Stability Review, No. 6, pp. 43-62.

13 Tsui, E. (2005) 'Asia Poised for Take-Off in CDOs', Financial Times, Capital Markets, 15 July.

14 The introduction of CDS indices contributed to hedging patterns thanks to greater standardisation. In the past, issuers would hedge unbalanced positions of customised CDOs through complex subordinated, multi-tranche structures ('transaction-based'), whose complexity inhibited transparent asset pricing. When the Dow Jones iTraxx ${ }^{\circledR}$ Europe index was created in June 2004 from the merger between two existing CDS indices, large issuers began to offer standard (single) CDO tranches on the $i \operatorname{Traxx}{ }^{\circledR}$ index, which replicate the behaviour of synthetic CDO claims on constituent names of the Dow Jones $i \operatorname{Traxx}{ }^{\circledR}$ index. These standardised (synthetic) CDO claims on liquid indices now offer a base correlation measure ('CDO delta') with the actual equity prices of (underlying) reference assets and constitute a dynamic 'market-based' hedge for issuers of bespoke and mostly privately transacted single-tranche transactions (arranged for single investors). Most recently, issuers also began to offer multi-tranche transactions with mezzanine tranches indexed to equity prices and tranchespecific CDS contracts on any retained CDO interest.

15 The annual issuance volume worldwide has grown more than fourfold from US\$48.1 billion in 1997 to US $\$ 193.5$ billion by the end of 2004. In 2004, one out of four new CDO deals was synthetic (US\$ 143.7 billion cash CDOs vs US\$ 49.8 billion funded synthetic CDOs), up from one out of 20 in 1997 (US\$ 45.5 billion cash CDOs vs US\$2.7 billion funded synthetic CDOs). With new asset classes being securitised in CDO transactions, the market size of outstanding CDO tranches has reached an estimated US $\$ 800$ billion by the end of 2004, which does not include privately placed transactions and unreported unsold tranches of bespoke, single-tranche synthetic CDOs.

16 Jobst, A. (2005) 'Tranche pricing in subordinated loan securitization', Journal of Structured Finance, Vol. 11, No. 2, pp. 64-96.

17 Shepherd, B. (2005) 'The Synthetic CDO Shell Game', Investment Dealer's Digest, 16 May.

18 Jobst, A. (2005) 'Need for Vigilance by CDO Investors', Financial Times, Comments \& Letters, 4 November. 
19 Jobst, A. (2005) 'Investors Must Heeds Those CDO Risks', Financial Times, Comments \& Letters, 19 April.

20 Although investors should expect the same returns for CDOs as for similar credit risk exposure in plain vanilla debt, their risk profile of CLOs tranches varies dramatically in response to changes in the valuation of the underlying (reference) asset.

21 Also Spain, Denmark and Sweden have established a long track record in the issuance of Pfandbrief-style investment products.

22 Skarabot, J. (2002) 'Securitization and Special Purpose Vehicle Structures', Working Paper, Haas School of Business, University of California at Berkeley. April.

23 The first ABS issue in its modern form was completed by Sperry Corporation, which issued computer leasebacked notes in 1985 (Kendall and Fishman, 1996).

24 Mastroeni, O. (2005) 'Pfandbrief-Style Products in Europe', Occasional Papers Series, European Central Bank, Frankfurt/Main.

25 Jobst, A. (2006c) 'European securitization: A GARCH model of secondary market spreads', Journal of Structured Finance, Vol. 12, No. 1, pp. 55-80.

26 Thus, synthetic arrangements effectively sidestep possible legal constraints associated with different loan characteristics and jurisdictions, mainly because most or all of the securitised assets are never sold to capital market investors.

27 Other, less relevant sinful activity under Islamic law in this context include hoarding, miserliness and extravagance.

28 These distinctive features derive from two religious sources, which aim at an equitable system of distributive justice: (i) the sharia'ah (or shariah), which comprises the qur'an (literally, 'the way') and the sayings and actions of the prophet Mohammed recorded in a collection of books know as the sahih hadith, and (ii) the figh, which represents Islamic jurisprudence based on a body of laws deducted from the shariah by Islamic scholars.

29 While the elimination of interest is fundamental to Islamic finance, shariah-compliant investment behaviour also aims to eliminate exploitation pursuant to Islamic law. Note also that Islamic law does not object to payment for the use of an asset. In fact, the earning of profits or returns from assets is encouraged.

30 See Archer and Karim ${ }^{27}$ as well as Iqbal and Llewellyn ${ }^{28}$ for an in-depth analysis.

31 Archer, S. and Karim, R.A., (eds.) (2002) 'Islamic Finance: Growth and Innovation', Euromoney Books, London.

32 Iqbal, M. and Llewellyn, D., (eds.) (2002) 'Islamic Banking and Finance: New Perspective on ProfitSharing and Risk', Edward Elgar Publishing, Ltd, Cheltenham/UK.
33 Islamic debt instruments come in the form of murabaha (or murabahah) (cost-plus sale), salam (deferred delivery sale), bai bithaman ajil (BBA) (deferred payment sale), istina (or istisna) (pre-delivery, project finance) and quard al-hasan (benevolent loan) contracts, which create borrower indebtedness from the purchase and resale contract of an asset in lieu of interest payments. Interest payments are implicit in an installment sale with instantaneous or future title transfer for promised payment of agreed sales price in the future.

34 In Islamic asset or quasi-debt instruments (al-ijarah leasing notes) the lender leases an asset to the borrower for a specified rent and term. The lessor (ie financier) acquires the asset either from the borrower or a third party (at the request of the borrower) and leases it to the borrower for an agreed sum of rental payable in installments according to an agreed schedule. The legal title of the asset remains with the financier throughout the tenure of the transaction, who bears all the risk associated with the ownership of the asset. The asset is returned to the borrower for the original sale price or the negotiated market price unless otherwise agreed (as opposed to debt-based contracts, which require a higher re-purchase price inclusive of quasi-interest payments). If the lessee does not exercise the option to buy the assets a pre-determined price at maturity, the lender will dispose of it in order to realise the salvage value.

35 In Islamic profit-sharing contracts (mudharaba and musharaka), lenders and borrowers agree to share any gains of profitable projects based on the degree of funding or ownership of the asset by each party.

36 In a debt-based synthetic loan, the borrower repurchase the assets from the lender at a higher price than the original sales price, whereas borrowers under a lease-back agreement repurchase the assets at the same price at the end of the transaction and pay quasi-interest in the form of leasing fees for the duration of the loan.

37 El Qorchi, M. (2005) 'Islamic Finance Gears Up', Finance and Development (December), International Monetary Fund (IMF), Vol. 42, No. 4, pp. 46-49.

38 The underlying asset transfer of Islamic lending arrangements provides collateralisation until the lender relinquishes ownership at the maturity date. In equitybased Islamic investments lenders do not have any recourse unless pre-mature termination enables the lender to recover some investment funds from the salvage value of project assets.

39 The relationship between the put and call values of a European option on a nondividend paying stock of a traded firm can be expressed as $P V(E)+C=S+P$. $P V(E)$ denotes the present value of a risky debt with a face value equal to exercise price $E$, which is continuously discounted by $\exp (-r T)$ at an interest rate $r$ over 
$T$ number of years. In our case of a lending transaction, the share price $S$ represents the asset value of the funded investment available for the repayment of the debt obligation at future value $E$.

40 The lease payments by the borrower are received wash out in this representation.

41 The call option is extendible in that the borrower has the right to renew the option to eventually acquire the asset by making the required rental payments or retiring any upcoming obligation according to the investment contract. The borrower pays a periodic premium for the call option to compensate the lender for the short position on the underlying asset until final repayment at maturity. The put option $+P(E)$ represents a series of cash-neutral, risk-free hedges of the lender's credit risk exposure. In corporate finance, borrowers (ie managers) would pay debt investors (ie lenders) a spread over the risk-free return (implied in the coupon yield) as option premium of their put on default risk if the asset value is insufficient to existing debt $E$ (strike price). As opposed to holders of risky corporate debt with payoff $P V(E)-P(E)$, financiers of such lending transactions own the underlying asset and hold a long put position on the firm value, which reflects the lender's full recourse for each installment repayment during the term of the transaction if the asset value $S$ falls below the promised repayment level $E$.

42 Kendall, L.T. and Fishman, M.J. (1996). 'A primer on securitization', MIT Press, Cambridge, MA. 